\title{
KEPUASAN PENGGUNA E-BANKING OLEH MAHASISWA UNIVERSITAS PENDIDIKAN GANESHA SEBAGAI NASABAH PT. BANK NEGARA INDONESIA (PERSERO), TBK KANTOR CABANG SINGARAJA
}

\author{
Ni Putu Rita Arini Indiawati \\ Jurusan Pendidikan Ekonomi \\ Universitas Pendidikan Ganesha \\ Singaraja, Indonesia \\ e-mail: puturitaarini@gmail.com
}

\begin{abstract}
ABSTRAK
Penelitian ini bertujuan untuk mengetahui (1) layanan e-Banking yang sering digunakan, (2) kendala yang sering dialami, (3) kepuasan pengguna e-Banking oleh nasabah $\mathrm{BNI}$, dan (4) layanan e-Banking yang harus ditingkatkan oleh PT. Bank Negara Indonesia Kantor Cabang Singaraja. Penelitian ini termasuk dalam jenis penelitian deskriptif kuantitatif dengan jumlah responden sebanyak 200 orang. Subjek penelitian ini adalah mahasiswa Universitas Pendidikan Ganesha angkatan tahun 2012 dan 2013 yang menggunakan e-Banking, sedangkan yang menjadi objek dalam penelitian ini adalah kepuasan nasabah. Metode pengumpulan data yang digunakan adalah kuesioner, yang selanjutnya dianalisis menggunakan teknik analisis data deskriptif dengan pendekatan kuantitatif. Hasil penelitian menunjukkan bahwa (1) layanan e-Banking yang sering digunakan oleh nasabah adalah penarikan tunai, (2) kendala yang sering dialami oleh nasabah dalam melakukan transaksi e-Banking adalah tidak mendapatkan print out laporan/resi, (3) kepuasan pengguna e-Banking berada pada kategori puas dengan skor 25.309 yang berada pada rentang skor 21.171-26.880, dan (4) layanan e-Banking yang harus ditingkatkan oleh PT. Bank Negara Indonesia Kantor Cabang Singaraja adalah penarikan tunai.
\end{abstract}

Kata kunci: kepuasan nasabah, e-Banking

\begin{abstract}
This research aimed to determine (1) e-Banking services which often used, (2) the constraints that are often experienced, (3) the satisfaction of users of e-Banking by BNI customers, and (4) e-Banking services which should be improved by PT. Bank Negara Indonesia Branch Office Singaraja. This research was a quantitative descriptive research with respondents as many as 200 people. The subjects of this study were students of Ganesha University of Education in 2012 and 2013 which use of eBanking, whereas the object of this research is customer satisfaction. Data collection method used was a questionnaire, which was analyzed by descriptive analysis technique with quantitative approach. The results showed that (1) e-Banking services are frequently used by customer was cash withdrawals, (2) problems often experienced in e-Banking transactions by customer was not getting a print out reports / receipts, (3) the satisfaction of users of e-Banking were at category satisfied with the score 25,309 which is in the range 21171-26880 scores, and (4) e-Banking services should be improved by PT. Bank Negara Indonesia Branch Office Singaraja was the cash withdrawal.
\end{abstract}

Keywords: costumer satisfaction, e-Banking

\section{PENDAHULUAN}

Persaingan bisnis dalam dunia perbankan semakin ketat baik di pasar domestik maupun internasional. Bank yang ingin berkembang dan mendapatkan keunggulan kompetitif harus mampu memberikan pelayanan yang baik kepada nasabah dibandingkan dengan kompetitornya. Kepercayaan dan kepuasan nasabah menjadi faktor keberhasilan usaha.

Untuk memenuhi kepuasan nasabah pada industri perbankan, kualitas pelayanan sangat penting bagi perusahaan untuk dikelola dengan baik 
agar tetap mendapat kepercayaan dari nasabah. Menurut Kotler (2002:42) "kepuasan pelanggan mengacu pada dua variabel, yaitu jasa yang dirasakan (perceived service) dan jasa yang diharapkan (expected service) oleh pelanggan". Menurut Lupiyoadi (2013:228), "kepuasan merupakan tingkat perasaan di mana seseorang menyatakan hasil perbandingan atas kinerja produk jasa yang diterima dengan yang diharapkan". Sedangkan menurut (Oliver, 2007) kepuasan adalah gagasan emosional yang dapat mempengaruhi penilaian dari jasa yang disediakan.Pelanggan dikatakan puas apabila jasa yang dirasakan melebihi apa yang diharapkan.

Sementara ketidakpuasan terjadi apabila pelanggan merasa jasa yang dirasakan kurang dari apa yang mereka harapkan. Menurut Kasmir (2004), dimensi dari kepuasan pelanggan dalam dunia perbankan antara lain (1) tampilan fisik, (2) daya tanggap, (3) jaminan, (4) kehandalan, dan (5) empati. Menurut Kotler (dalam Tjiptono dan Diana, 2003), bahwa pada prinsipnya pengukuran kepuasan pelanggan yang digunakan adalah metode survei kepuasan pelanggan dengan cara directly reported satisfaction, yaitu pengukuran yang dilaukan secara langsung melalui pertanyaan dengan alternatif jawaban sangat tidak puas, tidak puas, netral, puas, dan sangat puas.

Kepuasan nasabah tidak hanya memberikan keuntungan dalam jangka pendek akan tetapi mampu memberikan keuntungan dalam jangka panjang dan memberikan keunggulan daya saing bagi perusahaan penyedia jasa (bank). Apabila nasabah selalu merasa pelayanan yang diberikan oleh bank melebihi harapannya, artinya kecil kemungkinan nasabah beralih ke bank lain. Nasabah akan cenderung menggunakan kembali penyedia jasa (bank) yang mampu memberikan pelayanan yang memuaskan dan biasanya akan mempromosikan pelayanan yang didapatkan kepada calon nasabah lain.
Bank merupakan lembaga
keuangan yang mempunyai peranan
yang sangat strategis dalam
menggerakkan roda perekonomian
suatu negara. Menurut Undang-
Undang Nomor 10 Tahun 1998 (dalam
Veithzal dan Rifki, 2013) menyatakan
bahwa bank adalah badan usaha yang
menghimpun dana-dana dari
masyarakat dalam bentuk simpanan,
dan menyalurkannya kepada masyarakat dalam bentuk kredit dan bentuk-bentuk lainnya dalam rangka meningkatkan taraf hidup rakyat banyak. Sedangkan menurut Kasmir (2003:2), "bank adalah lembaga keuangan yang kegiatan utamanya adalah menghimpun dana dari masyarakat dan menyalurkan kembali dana tersebut ke masyarakat serta memberikan jasa bank lainnya". Menurut Thomas Suyatno (2003:4), "bank adalah suatu badan yang memiliki tugas utama yaitu sebagai perantara untuk menyalurkan penawaran dan permintaan kredit pada waktu yang telah ditentukan".

Revolusi teknologi informasi dalam dunia perbankan sangat pesat perkembangannya. Kemajuan teknologi informasi ikut menambah tantangan yang dihadapi oleh perbankan. Dukungan teknologi informasi bagi industri perbankan merupakan sebuah keharusan. Tidak dapat terbayangkan jika saat ini industri perbankan bergerak tanpa dukungan teknologi informasi yang memadai, oleh karena itu dalam menjalankan usahanya bank harus memberikan pelayanan terbaik bagi nasabahnya dan harus didukung dengan sarana dan prasarana yang memadai agar menarik minat masyarakat menjadi nasabah baru dan tidak pindah ke kompetitor lain. Salah satunya dengan mengeluarkan produk yang dapat memenuhi kebutuhan nasabah. Terobosan-terobosan baru produk dan jasa perbankan yang memiliki teknologi yang canggih akan memudahkan nasabah melakukan berbagai transaksi keuangan, diantaranya melaui media elektronik 
atau yang dikenal dengan Electronic Banking (e-Banking).

Menurut Veithzal dan Rifki (2013:361), Electronic Banking adalah layanan yang memungkinkan nasabah bank untuk memperoleh informasi, melakukan komunikasi, dan melakukan transaksi, perbankan melalui media elektronik seperti Automatic Teller Machine (ATM), phone banking, electronic fund transfer (EFT), Electronic Data Capture (EDC)/ Point Of Sales (POS), internet banking dan mobile banking.

Menurut Try Widiyono (2006:196), "electronic banking adalah layanan perbankan yang menggunakan berbagai kemudahan dalam bertransaksi sehingga seseorang dapat memilih berbagai layanan sesuai kebutuhannya". Berdasarkan pengertian di atas, dapat disimpulkan bahwa $e$ Banking adalah layanan perbankan yang menerapkan teknologi informasi melalui media elektronik untuk memudahkan nasabah dalam bertransaksi.

Bank menyediakan layanan $e-$ Banking untuk memenuhi tuntutan dan kebutuhan nasabah sebagai alternatif untuk melakukan transaksi perbankan. Melalui e-Banking, nasabah dapat mengakses produk dan jasa perbankan dengan menggunakan berbagai peralatan elektronik (intelligent electronic device) seperti Personal Computer (PC), Personal Digital Assistant (PDA), Anjungan Tunai Mandiri (ATM), kios, atau telephone. Transaksi e-Banking dapat dilakukan di mana saja, selama ada jaringan layanan data yang dapat diakses. Nasabah dapat melakukan transaksi dalam bentuk menu transaksi atau daftar transaksi yang disediakan selama 24 jam. Layanan e-Banking yang diberikan oleh bank menyediakan layanan yang bersifat informational, communicative dan transactional. Penyediaan layanan e-Banking hendaknya memperhatikan prinsip prudential banking, prinsip pengamanan dan terintegrasinya sistem teknologi informasi, cost effectiveness, perlindungan nasabah yang memadai serta searah dengan strategi bisnis bank.

Menurut Maryanto (2011:65), tujuan penggunaan layanan e-Banking adalah untuk memenuhi tuntutan dan kebutuhan nasabah sebagai alternatif media untuk melakukan transaki perbankan, tanpa nasabah datang ke bank atau Anjungan Tunai Mandiri (ATM), kecuali transki setoran dan tarikan uang tunai. Selain itu, transksi $e$ Banking dapat digunaan di mana saja selama ada jaringan layanan data dan dapat diakses selama 24 jam".

PT. Bank Negara Indonesia (Persero), Tbk sebagai salah satu bank yang berada dalam industri perbankan juga menyediakan layanan e-Banking. Layanan transaksi perbankan 24 jam $e$ Banking yang disediakan BNI seperti BNI ATM, BNI Phone Banking, BNI SMS Banking, dan BNI Internet Banking. Layanan e-Banking yang ditawarkan BNI ini mempunyai berbagai fitur menarik yang mampu memudahkan nasabah dalam bertransaksi. Fitur yang dapat diakses seperti transfer, pembayaran tagihan, pembelian tiket pesawat, pulsa isi ulang, cek saldo, mutasi rekening, info suku bunga, dan penarikan tunai. Layanan e-Banking diharapkan mampu memudahkan nasabah dalam bertransaksi, akan tetapi masih banyak nasabah yang belum menggunakan fasilitas layanan $e$ Banking secara maksimal. Hal tersebut disinyalir karena kurangnya informasi yang diberikan oleh pihak bank kepada nasabahnya dan masih banyaknya nasabah yang belum memahami cara penggunaan layanana e-Banking.

Universitas Pendidikan Ganesha merupakan salah satu universitas yang bekerja sama dengan PT. Bank Negara Indonesia. Beberapa bentuk kerja samanya adalah dalam pembayaran pendaftaran mahasiswa baru, pembayaran SPP, pembayaran Kuliah Kerja Nyata (KKN) dan pembayaran Praktek Pengalaman Lapangan (PPL). Khusus bagi mahasiswa angkatan 2012 dan 2013 secara langsung mereka telah 
menjadi nasabah BNI di mana Kartu Tanda Mahasiswa (KTM) mereka sekaligus merupakan kartu ATM BNI. Hal inilah yang juga harus diperhatikan oleh pihak bank. Mahasiswa Universitas Pendidikan Ganesha pasti akan sering melakukan transaksi melalui e-Banking untuk urusan pribadi maupun untuk urusan yang berhubungan dengan universitas. Maka dari itu, pihak bank harus mampu memberikan layanan $e$ Banking yang baik untuk memberikan kepuasan kepada nasabah khususnya kepada mahasiswa Universitas Pendidikan Ganesha sebagai nasabah PT. Bank Negara Indonesia Kantor Cabang Singaraja untuk membuktikan bahwa kinerja perusahaan perbankan dapat dikatakan sudah maksimal.

Hasil pengamatan di lapangan menunjukkan bahwa penggunaan $e$ Banking tidak semulus harapannya. Menurut hasil wawancara peneliti kepada beberapa nasabah, layanan $e$ Banking BNI pernah mengalami permasalahan seperti mesin ATM dalam keadaan offline, tidak adanya bukti transaksi saat melakukan penarikan secara otomatis, dan sering terjadi gangguan jaringan yang menghambat proses transaksi. Seperti yang ditelah dilansir di http://news.okezone.com bahwa Mabes Polri telah menetapkan beberapa kasus kriminilatis yang terjadi Kuta, Bali seperti pembobolan ATM yang dilakukan di 6 (enam) bank besar di Indonesia salah satunya adalah BNI. Aksi pembobolan ini tentunya membuat resah para nasabah, dan mampu mengakibatkan menurunnya kepercayaan nasabah pengguna $e$ Banking BNI khususnya mahasiswa Universitas Penddikan Ganesha. Berdasarkan uraian latar belakang di atas, penulis ingin meneliti mengenai "Kepuasan Pengguna e-Banking Oleh Mahasiswa Universitas Pendidikan Ganesha Sebagai Nasabah PT. Bank Negara Indonesia (Persero), Tbk Kantor Cabang Singaraja".

\section{METODE}

Penelitian ini menggunakan metode deskriptif dengan pendekatan kuantitatif. Data yang diperoleh berupa data tentang layanan e-Banking yang sering digunakan oleh mahasiswa Universitas Pendidikan Ganesha sebagai nasabah PT. Bank Negara Indonesia (Persero), Tbk Kantor Cabang Singaraja. Dimensi dari kepuasan nasabah yaitu tampilan fisik (tangibles), daya tanggap (responsiveness), jaminan (assurance), kehandalan (reliability), dan empati (empathy).. Penelitian ini dilakukan Universitas Pendidikan Ganesha Jalan Udayana Singaraja. Subjek dalam penelitian ini adalah mahasiswa Universitas Pendidikan Ganesha angkatan tahun 2012 dan 2013, sedangkan yang menjadi objek dalam penelitian ini adalah kepuasan nasabah yang terdiri dari lima dimensi yaitu tampilan fisik (tangibles), daya tanggap (responsiveness), jaminan (assurance), kehandalan (reliability), dan empati (empathy).

Populasi dalam penelitian ini
adalah mahasiswa Universitas
Pendidikan Ganesha angkatan tahun 2012 dan 2013 sebagai nasabah pengguna e-Banking pada PT. Bank Negara Indonesia (Persero), Tbk Kantor Cabang Singaraja. Dalam penelitian ini jumlah sampel yang digunakan sebanyak 200 orang dengan menggunakan teknik proporsional random sampling. Sampel penelitian untuk angkatan 2012 sebanyak 100 orang, sedangkan sampel untuk angkatan 2013 sebanyak 100 orang.

Jenis data yang digunakan dalam penelitian ini adalah data kuantitatif berupa data jumlah skor jawaban kuisioner mengenai kepuasan pengguna e-Banking. Dalam penelitian ini, sumber data yang digunakan dalam penelitian ini adalah data primer dan sekunder. Data primer dalam penelitian ini berupa hasil kuisioner tentang kepuasan nasabah. Sedangkan, data sekunder berupa dokumen jumlah mahasiswa tiap fakultas di Universitas Pendidikan Ganesha, dan dokumendokumen mengenai e-Banking yang 
didapatkan di PT. Bank Negara Indonesia (Persero), Tbk Kantor Cabang Singaraja. Metode pengumpulan data yang digunakan dalam penelitian ini adalah sebagai berikut (1) Wawancara tidak terstruktur dilakukan kepada beberapa mahasiswa Universitas Pendidikan Ganesha sebagai nasabah PT. Bank Negara Indonesia Kantor Cabang Singaraja untuk memperoleh data berupa pendapat mengenai kepuasan penggunaan layanan e-Banking. (2) Kuesioner, dipergunakan untuk memperoleh data ordinal yang merupakan penjabaran dari indikator variabel. (3) Dokumentasi digunakan untuk memperoleh data berupa jumlah mahasiswa angkatan tahun 2012 dan 2013 dari dokumen resmi internal tiap fakultas di Universitas Pendidikan Ganesha serta data-data mengenai layanan e-Banking dari web resmi bank yaitu www.bni.co.id.

Kuesioner, dipergunakan untuk memperoleh data ordinal yang merupakan penjabaran dari indikator variabel. Kuesioner yang digunakan akan menggunakan skala likert sebelum digunakan untuk mengumpulkan data di lapangan terlebih dahulu harus diuji tingkat validitas dan reabilitasnya. Menurut Sugiyono (2010) pengujian validitas tiap butir pertanyaan dalam kuesioner tersebut menggunakan analisis item yang mengkorelasikan skor tiap butir dengan skor total yang merupakan jumlah tiap butir soal, kemudian hasil korelasinya dibandingkan dengan nilai kritis pada signifikan 0,05. Syarat minimum instrumen penelitian dikatakan valid apabila nilai $r_{\text {hitung }}>r_{\text {tabel. }}$. Sedangkan suatu instrument dikatakan reliabel atau andal jika jawaban responden atas pertanyaan adalah konsisten atau stabil dari waktu ke waktu. Pengujian reliabilitas dapat menggunakan rumus Cronbach Alpha. Instrumen dikatakan reliabel untuk mengukur variabel bila memiliki nilai alpha lebih besar dari 0,6.

(1) Sesuai dengan perumusan masalah, tujuan penelitian, dan jenis data yang dikumpulkan maka analisis yang digunakan dalam penelitian ini adalah Menentukan skor tertinggi dan terendah dari keseluruhan alternatif jawaban, maka ditentukan terlebih dahulu jumlah pertanyaan pada masingmasing dimensi kepuasan nasabah yang akan diberikan kepada responden yaitu tangibles, responsiveness, assurance, reliability, dan emphaty. (2) Menentukan skor tertinggi (STT) dan skor terrendah (STR) dari keseluruhan alternatif jawaban. (3) Menentukan interval dari masing-masing dimensi kepuasan nasabah.

\section{HASIL DAN PEMBAHASAN Hasil}

Layanan e-Banking yang sering digunakan Oleh Mahasiswa Universitas Pendidikan Ganesha Sebagai Nasabah PT. Bank Negara Indonesia (Persero), Tbk Kantor Cabang Singaraja diklasifikasikan menjadi enam jenis transaksi yang sering digunakan nasabah dalam bertransaksi, yaitu inquiry atau cek saldo, penarikan tunai, transfer, pembayaran (kartu kredit, tagihan telepon, PLN, PDAM), pembelian produk (isi pulsa, tiket), dan administrasi (ganti pin) dengan melibatkan 200 responden diperbolehkan memilih lebih dari satu pilihan layanan e-Banking yang sering digunakan dapat dilihat pada Tabel 1.

Tabel 1 Layanan e-Banking BNI yang sering digunakan dalam bertransaksi

\begin{tabular}{lcc}
\hline \multicolumn{1}{c}{ Jenis Transaksi } & Responden & Persen (\%) \\
\hline Inquiry atau cek saldo & 151 & 75,5 \\
Penarikan Tunai & 200 & 100 \\
Transfer & 102 & 51 \\
Pembayaran (kartukredit, tagihantelepon, PLN, & 3 & 1,5 \\
PDAM) & 37 & 18,5 \\
Pembelian Produk (isi pulsa, tiket) & 12 & 6 \\
Administrasi (ganti pin) & \\
\hline
\end{tabular}


Berdasarkan hasil analisis pada Tabel 1 dapat dilihat bahwa sebanyak 151 responden dari 200 responden menggunakan layanan inquiry atau cek saldo, seluruh responden menggunakan layanan penarikan uang tunai, sebanyak 102 responden dari 200 responden menggunakan layanan transfer, sebanyak 3 responden dari 200 responden menggunakan layanan pembayaran (kartu kredit, tagihan telepon, PLN, PDAM,dll), sebanyak 37 responden dari 200 responden menggunakan layanan pembelian (isi pulsa, tiket), dan sebanyak 12 responden dari 200 responden menggunakan layanan administrasi (ganti pin) dalam bertransaksi melalui $e$ Banking BNI.

Kendala yang dialami dalam bertransaksi melalui e-Banking Oleh Mahasiswa Universitas Pendidikan Ganesha Sebagai Nasabah PT. Bank Negara Indonesia (Persero), Tbk Kantor Cabang Singaraja, berkaitan dengan hal ini 200 responden diperbolehkan memilih lebih dari satu pilihan jawaban mengenai kendala dalam bertransaksi melalui layanan e-Banking, sehingga didapatkan hasil dapat dilihat pada tabel 2.

\section{Tabel 2 Kendala bertransaksi melalui layanan e-Banking}

\begin{tabular}{lcc}
\hline \multicolumn{1}{c}{ Jenis Kendala dalam bertransaksi } & Responden & Persen (\%) \\
\hline Uang di ATM habis & 124 & 62 \\
Gangguan jaringan & 143 & 71,5 \\
Tidak mendapatkan print out laporan/resi & 161 & 80,5 \\
ATM rusak/offline & 61 & 30,5 \\
Keterlambatan laporan saat bertransaksi melalui & 56 & 28 \\
handphone & & \\
\hline
\end{tabular}

Berdasarkan hasil analisis pada Tabel 2 dapat diketahui kendala apa saja yang sering dialami nasabah dalam bertransaksi melalui e-Banking BNI. Sebanyak 161 responden dari 200 responden memilih bahwa kendala yang paling sering dialami adalah tidak adanya print out laporan/resi saat melakukan penarikan tunai secara otomatis di ATM BNI, sebanyak 143 responden dari 200 responden memilih kendala kedua yang sering dialami adalah gangguan jaringan, sebanyak 124 responden dari 200 responden memilih bahwa kendala ketiga adalah kehabisan dana di ATM, seebanyak 61 responden dari 200 responden memilih kendala keempat yang sering dialami adalah saat menjumpai ATM rusak/offline, dan sebanyak 56 responden dari 200 responden memilih kendala kelima yang sering dialami dalam bertransaksi melalui e-Banking adalah keterlambatan laporan saat bertransaksi melalui handphone.

Kepuasan Pengguna e-Banking Oleh Mahasiswa Universitas Pendidikan Ganesha Sebagai Nasabah PT. Bank Negara Indonesia (Persero), Tbk Kantor Cabang Singaraja. Hasil analisis yang diperoleh menunjukkan kepuasan pengguna e-Banking perdimensi maupun secara total tersebut dapat dilihat pada Tabel 3.

Tabel 3 Kepuasan Pengguna e-Banking

\begin{tabular}{clcc}
\hline No & \multicolumn{1}{c}{ Dimensi } & Skor & Kategori \\
\hline 1 & Tangibles & 6.714 & Puas \\
2 & Responsiveness & 5.897 & Sangat Puas \\
3 & Assurance & 5.116 & Sangat Puas \\
4 & Reliability & 3.982 & CukupPuas \\
5 & Empathy & 4.138 & Puas \\
& Total & 25.847 & Puas \\
\hline
\end{tabular}


Berdasarkan hasil analisis Tabel 3, menunjukkan bahwa skor total dari lima dimensi kepuasan nasabah berada pada kategori puas dengan skor 25.847 yang berada pada rentang skor 21.17126.880. Pada dimensi tangibles berada pada kategori puas dengan skor 6.714 yang berada pada rentang 5.441-6.720, dimensi responsiveness berada pada kategori sangat puas dengan skor 5.897 yang berada pada rentang 5.881-7.000, dimensi assurance berada pada kategori sangat puas dengan skor 5.116 yang berada pada rentang 5.041-6.000, dimensi reliability berada pada kategori cukup puas dengan skor 3.982 yang berada pada rentang 3.121-4.080, dimensi empathy berada pada kategori puas dengan skor 4.138 yang berada pada rentang 3.401-4.200.

Layanan e-Banking yang harus ditingkatkan Oleh PT Bank Negara Indonesia (Persero), Tbk Kantor Cabang Singaraja. Berdasarkan hasil kuisioner yang telah disebarkan kepada 200 responden diperoleh hasil bahwa layanan e-Banking yang diharapkan untuk ditingkatkan, penulis mengklasifikasikan dalam enam jenis transaksi, yaitu inquiry atau cek saldo, penarikan tunai, transfer, pembayaran (kartukredit, tagihantelepon, PLN, PDAM), pembelian produk (isi pulsa, tiket), dan administrasi (ganti pin). Hasil analisis tersebut dapat dilihat pada tabel 4.

Tabel 4 Layanan e-Banking yang perlu ditingkatkan

\begin{tabular}{lcc}
\hline \multicolumn{1}{c}{ Jenis Transaksi } & Responden & Persen (\%) \\
\hline Inquiry atau cek saldo & 34 & 17 \\
Penarikan Tunai & 108 & 54 \\
Transfer & 97 & 48,5 \\
Pembayaran (kartukredit, tagihan telepon, PLN, & 16 & 8 \\
PDAM) & 21 & 10,5 \\
Pembelian Produk (isi pulsa, tiket) & 13 & 6,5 \\
Administrasi (ganti pin) &
\end{tabular}

Berdasarkan hasil analisis pada Tabel 4 dapat diketahui layanan $e$ Banking yang harus ditingkatkan dalam bertransaksi melalui e-Banking BNI. Sebanyak 34 responden dari 200 responden memilih layanan yang harus ditingkatkan adalah layanan inquiry atau cek saldo, sebanyak 108 responden dari 200 responden memilih layanan yang harus ditingkatkan adalah layanan penarikan tunai, sebanyak 97 responden dari 200 responden memilih layanan yang harus ditingkatkan adalah layanan transfer, sebanyak 16 responden dari 200 responden memilih layanan yang harus ditingkatkan adalah layanan pembayaran (kartu kredit, tagihan telepon, PLN, PDAM), sebanyak 21 responden dari 200 responden memilih layanan yang harus ditingkatkan adalah layanan dalam pembelian (isi pulsa,tiket), dan sebanyak 13 responden dari 200 responden memilih layanan administrasi (ganti pin) harus ditingkatkan.

\section{Pembahasan}

Kepuasan pengguna e-Banking oleh mahasiswa Universitas Pendidikan Ganesha sebagai nasabah PT. Bank Negara Indonesia (Persero), Tbk Kantor Cabang Singaraja menunjukkan skor total dari lima dimensi kepuasan nasabah berada pada kategori puas. Dilihat dari hasil penelitian yang sesuai dengan fakta bahwa secara keseluruhan nasabah merasa puas dengan layanan e-Banking yang disediakan.

Temuan ini juga didukung dengan pernyataan Maryanto (2011), yang menyatakan keuntungan melakukan transaksi menggunakan $e$ Banking adalah dapat bertransaksi kapan saja dan di mana saja, efisien, dan aman. Penelitian ini juga sejalan dengan teori dari Try Widiyono (2006), yang menyatakan e-Banking adalah layanan yang mampu memberikan kemudahan dalam bertransaksi sehingga seseorang dapat memilih 
berbagai layanan sesuai kebutuhannya. Jadi sesuai dengan teori, layanan $e$ Banking dianggap mampu memberikan kemudahan karena nasabah dapat mengakses informasi, melakukan transaksi melalui media elektronik tanpa harus datang langsung ke bank sehingga mampu mengefisienkan waktu. Sesuai dengan pernyataan Oliver (2007) bahwa kepuasan adalah gagasan emosional yang dapat mempengaruhi penilaian dari jasa yang disediakan, sehingga hal inlah yang menjadi salah satu alasan nasabah merasa puas dengan layanan $e$ Banking yang disediakan karena dianggap mampu memenuhi kebutuhan dalam melakukan transaksi perbankan.

Kepuasan nasabah perdimensi menunjukkan dimensi tangibles berada pada kategori puas, dimensi responsiveness berada pada kategori sangat puas, dimensi assurance berada pada kategori puas dimensi reliability berada pada kategori cukup puas, dimensi empathy berada pada kategori puas. Penelitian ini memiliki persamaan dengan penelitian yang dilakukan Andi Lesmana (2008) adalah pada dimensi reliability yang berada pada kategori cukup puas. Hal ini menunjukkan bahwa nasabah hanya sebatas cukup puas dengan kehandalan bank dalam memberikan pelayanan yang telah dijanjikan dengan cepat, akurat, dan tepat waktu.

Layanan e-Banking yang sering digunakan oleh nasabah BNI adalah fitur transaksi penarikan tunai. Pada penelitian ini, responden atau nasabah yang dijadikan sampel adalah mahasiswa Universitas Pendidikan Ganesha. Oleh karena itu, fitur transaksi penarikan tunai merupakan layanan yang paling sering digunakan oleh nasabah untuk memenuhi berbagai macam kebutuhan. Hasil penelitian ini sejalan dengan penelitian Satria Hendra (2011) yang menyatakan bahwa layanan yang paling sering digunakan oleh nasabah BNI Medan Sunggal adalah fitur transaksi penarikan tunai.

Pada penelitian ini, diketahui bahwa kendala yang paling sering dijumpai nasabah saat melakukan transaksi melalui e-Banking adalah tidak adanya print out laporan/resi saat melakukan penarikan secara otomatis. Hal ini menujukkan bahwa prosedur BNI memang berbeda dengan bank-bank yang lain, karena pada PT. Bank Negara Indonesia print out laporan hanya didapatkan apabila nasabah melakukan cek saldo terlebih dahulu sebelum melakukan penarikan tunai. Selain itu, diketahui bahwa layanan $e$ Banking yang perlu ditingkatkan adalah penarikan tunai. Sesuai dengan teori mengenai e-Banking yang penulis dapatkan di website resmi BNI (www.bni.co.id), menyebutkan bahwa layanan e-Banking $\mathrm{BNI}$ siap melayanai nasabah selama 24 jam, guna melakukan transaksi perbankan yang meliputi penarikan tunai, inquiry saldo, transfer, pembayaran tagihan, pembelian produk, ganti PIN, hingga setoran tunai (tersedia di lokasi ATM tertentu) tanpa terikat waktu. Jadi teori di atas sejalan dengan penelitian penulis karena penarikan tunai merupakan salah satu fitur transaksi yang menyebabkan nasabah menggunakan layanan e-Banking karena fitur penarikan tunai merupakan fitur yang dibutuhkan semua nasabah dan paling sering digunakan oleh nasabah.

\section{SIMPULAN DAN SARAN Simpulan}

Berdasarkan hasil analisis data dan pembahasan hasil penelitian maka dapat ditarik simpulan sebagai berikut. (1) Layanan e-Banking yang paling sering digunakan oleh nasabah adalah penarikan tunai. Hal ini ditunjukkan dengan adanya jawaban 200 responden $(100 \%)$ yang memilih menggunakan fitur layanan penarikan tunai yang mampu memberikan kemudahan bagi nasabah saat ingin mengambil dana di lokasi ATM di mana saja dan kapan saja. (2) Kendala yang sering dialami nasabah dalam bertransaksi melalui layanan e-Banking adalah tidak adanya print out laporan/resi saat melakukan penarikan tunai secara otomatis di ATM 
BNI. Hal ini ditunjukkan dengan adanya jawaban 161 responden (80,5\%) yang memilih bahwa kendala yang dialami dalam bertransaksi adalah tidak adanya print out laporan/resi dalam penarikan secara otomatis karena print out laporan/resi didapatkan saat melakukan transaksi apabila nasabah melakukan cek saldo terlebih dahulu. (3) Kepuasan pengguna e-Banking oleh mahasiswa Universitas Pendidikan Ganesha sebagai nasabah PT. Bank Negara Indonesia (Persero), Tbk Kantor Cabang Singaraja menunjukkan bahwa skor total dari lima dimensi kepuasan nasabah yaitu tangibles, responsiveness, assurance, reliability, dan empathy berada pad skor 25.847 yang berada pada rentang skor 21.17126.880 dengan skor tersebut diketahui bahwa kepuasan pengguna e-Banking berada pada kategori puas. Layanan e-Banking yang perlu ditingkatkan adalah penarikan tunai. Hal ini ditunjukkan dengan jawaban 108 responden yang memilih fitur layanan tersebut agar lebih ditingkatkan dan dapat memberi kenyamanan bagi nasabah.

\section{Saran}

Berdasarkan simpulan diatas, maka dapat dikemukakan beberapa saran sebagai berikut. (1) Pihak bank perlu meningkatkan dan mengoptimalkan pelayanan e-Banking yang diberikan kepada nasabah pada dimensi ini melalui peningkatan sumber daya manusia dan teknologi sehingga tercapai target yang ditetapkan dan memberikan kepuasan bagi nasabah, serta memberikan citra baik bagi pihak bank. (2) Pihak bank diharapkan menyediakan mesin untuk menabung atau Cash Deposit Machine yang mampu memudahkan nasabah untuk menabung tanpa harus datang langsung ke bank. (3) Bagi peneliti selanjutnya diharapkan mampu mengembangkan pembahasan lebih mendalam tentang e-Banking baik itu BNI ATM, BNI SMS Banking, BNI
Phone Banking, dan BNI Internet Banking agar dapat lebih meningkatkan generalisasi penelitian.

\section{DAFTAR PUSTAKA}

Abdul Majid, Suharto. 2009. Customer Service dalam Bisnis Jasa Transportasi. Jakarta: PT. Raja Grafindo Persada.

Amir, M.Taufik.2005. Dinamika Pemasaran Jelajahi dan Rasakan. Jakarta: PT. Raja Grafindo Persada.

Andi, Lesmana. 2008. "Analisis Kepuasan Nasabah Terhadap Pelayanan Bank Mandiri (Persero) Tbk Di Bagian Retail \& Consumer Risk Group". Skripsi (tidakditerbitkan). Jurusan Manajemen, Universitas Gunadarma.

Arikunto. 2006. Prosedur Penelitian Suatu Pendekatan Praktek Edisi Revisi VI.

Cetakan Ketigabelas. Jakarta: PT Rineka Cipta.

Athena, Adharawati. 2011. Analisis Efektivitas Teknologi Informasi Mobile Banking Bagi Nasabah Pada bank bjb Cabang Utama Bandung".

Skripsi (tidakditerbitkan). Jurusan Akuntasi ,Universitas Diponegoro.

Irawan, Handi. 2007. 10 Prinsip Kepuasan Pelanggan. Paradigma Baru Merebut Hati Pelanggan Untuk Memenangkan Persaingan. Jakarta: PT. Elex Media Komputindo.

Ismail. 2011. Manajemen Perbankan Dari Teori Menuju Aplikasi. Jakarta: Kencana Prenada Media. 
Kasmir. 2003. Dasar-Dasar Perbankan. Jakarta: PT. Raja Grafindo Persada.

-------, 2004. Pemasaran Bank. Jakarta: Prenada Media

------, 2011. Dasar-Dasar Perbankan. Jakarta: PT. Raja Grafindo Persada.

Kotler, dkk. 2002. Dasar-Dasar Pemasaran Jilid I Alih Bahasa Alexander Sindorodan Benyamin Molan. Jakarta: Prenhalindo.

Kotler, Philip. 2003. Manajemen Pemasaran. Edisi Kesebelas. Jakarta: Indeks Kelompok Gramedia.

Kotler dan Keller. 2007. Manajemen Pemasaran Edisi KeduaBelas Jilid 2 Bahasa Indonesia. Jakarta: PT Indeks Kelompok Gramedia.

Lupiyoadi, Rambat. 2013. Manajemen Pemasaran Jasa Berbasis Kompetensi. Edisi ke-3. Jakarta: Salemba Empat.

Nasution, M. N. 2004. Manajemen Jasa Terpadu. Jakarta: PT. Ghalia Indonesia.

Nurastuti, Wiji. 2011. Teknologi Perbankan. Yogyakarta : Graha IImu.

Oliver, Sandra. 2007. Strategi Public Relations. Jakarta :Penerbit Erlangga.

Rangkuti, Freddy. 2004. Riset Pemasaran Cetakan Kelima. Jakarta: PT Gramedia

Riduwan. (2010). Skala Pengukuran Variabel-Variabel Penelitian. Bandung: Alfabeta.
Sugiyono. 2004. Metodelogi Penelitian Administrasi.

Bandung: Alfabeta.

Supriyono, Maryanto. 2011. Buku Pintar Perbankan. Yogyakarta : CV. Andi Offset

Surmani, Murti dan Salamah Wahyuni. 2006. Metode Penelitian Bisnis. Yogyakarta: CV Andi Offset

Suyatno, Thomas, dkk. 2003. Kelembagaan Bank. Jakarta: PT. Gramedia Pustaka Utama

Tjiptono, Fandy dan Anastasia Diana. 2003. Total Quality Managemen Edisi Revisi. Yogyakarta: CV Andi Offset.

Tjiptono, Fandy dan Chandra, G. 2005. Service Quality and Satisfaction. Yogyakarta: CV Andi Offset.

Tjiptono, Faandy. 2006. Manajemen Jasa.Yogyakarta: CV. Andi Offset.

Umar, Husein. 2005. Metode Penelitian Untuk Skripsi dan Tesis Bisnis. Jakarta: PT. Raja Grafindo Persada.

Veitzal Rivai dan Rifki Ismail. 2013. Islamic Risk Management For Islamic Bank. Jakarta : PT. Gramedia Pustaka Utama

Widiyono, Try. (2006). Aspek Hukum Operasional Transaksi Produk Perbankan Di Indonesia. Bogor: Ghalia Indonesia.

www.bni.co.id (diakses pada tanggal 23 Februari 2014)

Zaenal,Abdul. 2010. Kasus Pembobolan Anjungan Tunai Mandiri di Bali. Tersedia pada : http://news.okezone.com ( diakses pada tanggal 09 Januari 2014) 